\title{
El espejo: un misterio desde cuatro contigüidades
}

\section{The Mirror: Mystery from four contiguities}

\author{
Kuzmina EUGENIA \\ Universidad de Navarra \\ artevgenialetras@gmail.com
}

Recibido: 22-02-2011

Aceptado: 23-07-2012

\section{Resumen}

El espejo se convierte en una noción transversal a la metafísica, la historia de la filosofía, la antropología, la semiótica, la historia del arte, el psicoanálisis, la filología e incluso la teología y la estética. Este fenómeno tiene una conexión asociativa con la capacidad humana de la autoconciencia, la reflexión, la percepción de la dualidad de la naturaleza humana. Un estudio sistemático de las representaciones del espejo en el arte contemporáneo y la estética mostraría la utilización recurrente del espejo vacío, del espejo roto, del espejo como bipartición andrógina y del espejo como referente del doble de la persona. Esta percepción de la ausencia visual y de la duplicación no significa necesariamente la abolición del yo, sino un grado mayor de profundización en la comprensión del ser en su dimensión espiritual, lúdica, filosófica y simbólica.

Palabras clave: Espejo, metáfora, doble, cronotopo, juego, androginia, imagen, simultaneidad.

\section{Abstract}

The mirror becomes a transversal notion of metaphysics, history of philosophy, anthropology, semiotics, art history, psychoanalysis, philology, and even theology and aesthetics. This phenomenon has a connection associated with the human capacity for self-awareness, reflection, perception of the duality of human nature. A systematic study of representations of the mirror in contemporary art and aesthetics 
shows the recurrence of the empty mirror, the broken mirror and the mirror as the referent of the double of the person. This perception of the visual absence of duplication does not necessarily mean the abolition of self, but a higher degree of deepening in the comprehension of being in its spiritual, playful, philosophical and symbolic dimension.

Keywords: mirror, metaphor, reflection, double, chronotope, game, image, androgyneity, simultaneity.

\section{Introducción}

Desde tiempos remotos, el espejo ha ejercido fascinación sobre el espíritu humano. La imagen duplicada, triplicada o invertida que proporciona o esconde algo enigmático, sea reflejo en la superficie del agua, en cuarzo hialino, en el espejo de metal o de cristal con amalgama, tiene una conexión asociativa con la capacidad humana de la autoconciencia, de la reflexión, de la percepción de la dualidad de la naturaleza humana. Se vincula también al arte representativo, que, aún sin quererlo, no puede separarse de la capacidad refractaria. En este sentido es reveladora la observación que hace Baltrusaitis: "sean cuales sean su forma y destino, el espejo es siempre un prodigio donde la realidad y la ilusión se codean y confunden. La revelación de su propia imagen al hombre fue su primer hecho. Esta revelación física y moral fascinaba a los filósofos [...]. El espejo es el atributo de la prudencia y encarna la sabiduría. Las «reflexiones» en el pensamiento y en el espejo se designan con la misma palabra"1.

La imagen especular es atractiva para la mente humana porque genera la ilusión de una simetría perfecta. Así lo expresa S. Dalí: "Narciso, / ¿comprendes? / La simetría, divina hipnosis de la geometría del espíritu, / colma ya tu cabeza con ese sueño incurable, vegetal, atávico y lento". 2

Al desplegar en sentido inverso los acontecimientos y los objetos en su panta1la transparente, el espejo crea el doble incorpóreo del universo. Asimismo, el espejo está relacionado con los conceptos de proporción y de medida, en tanto que puede servir como paradigma de la disposición simétrica del cuerpo humano. Según R. Caillois, el hombre está construido sobre el modelo de la simetría especular ${ }^{3}$. El

\footnotetext{
${ }^{1}$ Baltrusaitis, J., Ensayo sobre una leyenda cientifica. El espejo. Revelaciones, ciencia-ficción y falacias, Madrid, Miraguano-Polifemo, 1978, p. 281.

2 Dali, S., La metamorfosis de Narciso. Poema paranoico, manuscrito conservado en la Fundació Gala-Salvador Dali, Figueres, 1937.

3 Caillois, R., Cohérences aventureuses. Esthétique généralisée. Au coeur du fantastique. La dissymétrie, Paris, Gallimard, 1973, p. 214.
} 
corte transversal divide el cuerpo humano en dos partes, una de las cuales aparece como reflejo de la otra. Efectivamente, el desnudo de una figura humana presenta una simetría bilateral casi perfecta. Parte de su atractivo, tanto en la realidad como en el arte, reside en la identificación de los lados derecho e izquierdo del cuerpo mediante una simetría especular ${ }^{4}$.

La cualidad esencial del espejo consiste en que puede reflejar simétricamente los detalles situados en el lado opuesto, intercambiando la lateralidad izquierdaderecha. A la Alicia de Lewis Caroll, al asomarse al espejo situado sobre el mantel parlante parece como si todas las cosas de la habitación fueran al revés. La comprensión de estas reglas de simetría es, en realidad, una subida a la superficie, el repudio de la falsa profundidad, el descubrimiento de que todo ocurre en la frontera entre dos lados opuestos ${ }^{5}$. Esta superficialidad de los espejos, aplicada a la escritura, conlleva nuevos matices. El espejo descodifica de forma instantánea un mensaje escrito con letras invertidas. Por lo tanto, se podría decir que el espejo funciona como una herramienta mágica capaz de conservar la información. En este sentido puede ser ilustrativo mencionar a Leonardo, quien, al escribir sus manuscritos, utilizaba una forma de escritura invertida que solo podía ser leída con la ayuda de un espejo.

El fenómeno del espejo existe en la cultura en tres proyecciones: la idea del reflejo especular, la imagen del espejo y la del espejo-objeto, y cobra vida en el espacio de la cultura material, espiritual y artística. La conciencia humana ha concedido al espejo los valores estéticos, axiológicos y gnoseológicos que, a su vez, determinaron los papeles polifuncionales y polisemánticos del objeto en la cultura. El significado estético del espejo está relacionado con las cualidades técnicas de las superficies refractarias. La función axiológica del espejo la constituye la capacidad del objeto de actuar como indicador de los juicios valorativos. El aspecto gnoseológico del espejo consiste en que puede servir como un medio de aprendizaje y autoconocimiento.

El aspecto cognitivo del espejo aparece por primera vez en la Antigüedad en los escritos de Diógenes sobre Sócrates, según los cuales el espejo no reflejaba solamente los rasgos físicos, sino que testimoniaba la condición espiritual del ser humano. Según Séneca, el espejo era una herramienta para perfeccionarse a sí mismo6. La función epistemológica del espejo es también un tema recurrente en la teoría artística. Alberti concibe el espejo como una herramienta útil para el trabajo.

\footnotetext{
${ }^{4}$ Esta asociación del torso con la simetría aparece ya en Policleto que afirmaba: "se alaba una estatua llamada Canon, que recibió tal nombre por ser exacta la simetría de todas las partes en relación unas con otras", en Tatarkiewicz, W., Historia de la estética. La estética antigua, Madrid, Akal, 1987, p. 84. 5 Sobre la interpretación ontológica de la simetría especular, cfr. Deleuze, G., Lógica del sentido, Barcelona, Paidós, 1989, pp. 27-34.

${ }^{6}$ Frontisi-Ducroux, F., Vernant, J. P., Dans l'oeil du miroir, Paris, Éditions Odile Jacob, 1997, p. 155.
} 
Leonardo sigue a Alberti en su interpretación del espejo como maestro del artista. Sin embargo, su concepción del espejo se enriquece con una referencia a la posibilidad del uso del espejo como medio de perfeccionamiento espiritual: "el espíritu del pintor debe ser semejante al espejo que se transforma sin cesar de acuerdo al color de las cosas que refleja"'. Miguel Ángel relaciona el espejo con el conocimiento trascendental: "en ningún sitio me muestra Dios su gracia mejor que sobre un bello y mortal velo al que amo solo porque lo refleja"

La implicación estética del espejo está relacionada con el concepto de mímesis, en tanto que reproduce la apariencia de las cosas. Desde la época clásica en la tratadística filosófica y artística el concepto del espejo se utilizará como metáfora de adecuación entre la creación y la imitación de naturaleza.

El escenario teatral es otro ámbito donde se revela la función estética del espejo. Para Aristóteles el teatro es la imitación de la vida; a través de él el hombre experimenta la catarsis espiritual ${ }^{9}$. La interacción entre la mimesis y el espejo en el teatro se manifiesta también en las puestas en escena propiamente dichas. Tomemos como ejemplo los experimentos de M. Chagall. En su trabajo para el Teatro Judío, el artista bielorruso entabla una reciprocidad especular entre las figuras pintadas y los actores vivos, de modo que la creación pictórica se convierte en la mímesis del arte teatral, y a su vez, el acto teatral se percibe como la imagen pictórica vivificada. Según el testimonio de un crítico teatral: "cuando el telón se levantó, los paneles pictóricos de Chagall y los decorados, con los actores en el escenario, se hacían eco. Y teníamos derecho a preguntarnos por qué estas criaturas chagallianas se movían y hablaban en lugar de permanecer inmóviles y mudas como en los cuadros"10.

El espejo en su dimensión material forma parte del proceso histórico y su destino es inseparable del contexto de la cultura. Se caracteriza también por el dinamismo en tanto que su orientación conceptual y perceptiva se enriquece en cada era con nuevas implicaciones semánticas. En cada época el hombre ha definido su visión del objeto, le ha asignado ciertos valores y funciones, ha reconsiderado su estatuto. Como resultado de ello, cada época ha configurado una imagen determinada del espejo.

Para los griegos, el espejo es un concepto esencial que tiene carácter polisemántico. En primer lugar, el reflejo especular estaba relacionado con la mujer, la belleza y el placer erótico. Así lo define Vernant, especialista en la cultura clásica: "den-

\footnotetext{
7 Navarro de Zuvillaga, J., Mirando a través. La perspectiva en las artes, Barcelona, Ediciones del Serbal, 2000, p. 103.

8 Citado en Tatarkiewicz, W., Historia de la estética moderna 1400-1700, Madrid, Akal, p. 185.

9 Este postulado será retomado por otros autores entre los que figuran Shakespeare, Hugo, Pirandello, etc. Sobre este tema cfr. Navarro de Zuvillaga 2000, op.it. (nota 7), pp. 217-218.

10 Efros, A., "Los artistas del teatro de Granovsky", Iskusstvo, 13 (1928), p. 62.
} 
tro de la existencia cotidiana de los antiguos, el espejo viene a ser cosa de mujeres. $\mathrm{Su}$ superficie remite al resplandor de su belleza, al brillo de su poder de seducción, a las ondulaciones de sus cabellos y a su tez delicada"11.

El espejo, en el contexto ritual, configura una imagen del vacío en tanto que se niega a reflejar la apariencia del sujeto y del mundo objetual, poniendo de manifiesto lo divino. La descripción del espejo colocado en el santuario de Démeter que refiere Pausanias puede ser instructiva al respecto: "aquél que se mire en él [...] no discerniría de sí mismo más que un oscuro reflejo, debilitado o indistinguible [...]; por el contrario, las figuras de las diosas [...] aparecen recortadas con claridad en el espejo [...]"12.

En los fenómenos implicados en la mirada y la reflexión se desvelaban tanto los aspectos mentales como los visuales, ya que participan de un proceso recíproco del conocimiento/contemplación. El espejo permite el juego refractario del voyerismo y del exhibicionismo imbricados en la mirada activa, como ocurre con el espejo de Demóstenes, que refleja la elocuencia del orador y no su apariencia física13; pero, al mismo tiempo, aglutina la mirada pasiva de Narciso y su ensimismamiento. En el concepto del espejo queda implícita la problemática de la autoperfección y del conocimiento filosófico, como es el caso de Sócrates y Apuleo ${ }^{14}$. La propia imagen, rostro, en griego prósopon, es aquello que uno presenta de sí mismo a la mirada del otro, a saber, es una especie de encuentro con un doble: "[...] uno accede a sí mismo proyectándose al exterior, como si se tratase de otro"15. El espejo revela la verdad, cualquier indicio de impureza se percibe en su superficie refractaria, como señalan Aristóteles y Proclo. Vernant escribe al respecto: "en su tratado De insomnis, Aristóteles señala que los espejos se empañan cuando se miran en ellos las mujeres durante la menstruación [...]. Las imágenes de los espejos, escribe también Proclo en su comentario a la República, conservan por «simpatía» las figuras de los cuerpos de los que provienen"16.

Se recurre a la metáfora del espejo para hablar de la dependencia ontológica de una realidad secundaria con respecto a una realidad primaria. En esta relación, Platón y la tradición derivada de su pensamiento remiten al reflejo de la idea en el mundo sensible, al reflejo del absoluto divino en el fondo del alma humana.

Por último, el espejo se asocia a las artes figurativas y a la mímesis, como se manifiesta en la filosofía de Platón. En su estudio comparado sobre la teoría de la

\footnotetext{
11 Vernant, J.P., El individuo, la muerte y el amor en la antigua Grecia, Barcelona, Paidós, 2001, p. 114.

12 Ibidem, p. 113.

13 Cfr.Melchior-Bonnet, S., Histoire du Miroire, Paris, Imago, 1994, p. 172.

14 Ibidem, pp. 168-170.

15 Vernant 2001, op. cit. (nota 11), pp. 114-115.

16 Ibidem, p. 122.
} 
imitación clásica y la de los autores modernos, Hallivel reivindica su doble significado: "hay dos caras de este punto, con la primera se llega a la condición semántica de los contenidos de representación de una imagen, la segunda se refiere a las condiciones ópticas de la mimesis visual" 17 .

Más adelante, el investigador americano se detiene brevemente en el análisis de la categoría de la belleza manifestado en las artes plásticas. Según sus propias palabras, "hay algunas referencias platónicas a la belleza y el reflejo en la pintura y otras artes visuales $[\ldots]$ podemos detectar detrás de muchas de ellas lo que podría denominarse la ética de la forma"18.

El espejo en el contexto medieval y renacentista fue utilizado para resaltar la divina trascendencia en la cual el hombre hallaba la luz de su verdad; servía asimismo para configurar las metáforas de la belleza. Un ejemplo revelador de la primera dimensión aparece en las exploraciones de Nicolás de Cusa que advierte en el espejo una metáfora de las capacidades mentales del hombre que, a través de su esfuerzo intelectual, se asemeja a Dios ${ }^{19}$. Esta concepción es inherente también a las imágenes refractarias de los primitivos flamencos que establecen la analogía entre el macrocosmos y el microcosmos. En lo referente a la propagación de la belleza femenina reflejada en el espejo, ésta aparece en las creaciones pictóricas, literarias y estéticas de los venecianos.

En el Barroco la imagen del espejo adquiere connotaciones tropológicas ${ }^{20}$. Así, este motivo aparece con frecuencia en las representaciones de vanitas que aluden al carácter perecedero de la vida humana y a la necesidad de tener presentes por los valores morales y trascendentales. Junto a esto, se advierte la transformación del objeto en elemento de decoración. Por último, se denota la capacidad de las superficies refractarias para multiplicar al referente original, lo cual repercute en la formulación de la visión metafórica del espejo que se aprecia en la proliferación de las imágenes-textos. En este sentido, son paradigmáticos los espejos "reflexivos" de las Meninas de Velázquez.

En filosofia, la imagen del espejo como metáfora de la capacidad humana puramente mimética es reemplazada paulatinamente por la idea de expresión. Esta visión se hace patente en el pensamiento de Leibniz, que confiere a la metáfora del espejo una doble dimensión, como reflejo del universo y como expresión activa del

17 Cfr. Hallivel, S., The aesthetics of mimesis: ancient texts and modern problems, Princeton, Princeton University Press, 2002, p. 127.

18 Ibidem, p. 131.

19 Para la bibliografía del tema, cfr. Kuzmina, E. «El pensamiento estético de Nicolás de Cusa en el espectro de la luz renacentista», en Pensamiento y cultura, 13 (2010), pp. 37-53.

20 El término es utilizado por U. Eco en la clasificación de los niveles interpretativos de los textos sagrados y alude a la dimensión moral de los mismos. Cfr. Eco, U., Evolución de la estética medieval, San Petersburgo, Azbooka-clásica, 2004, pp.125-127. 
sujeto. Por otro lado, la imagen del espejo se emplea para definir la sustancia concebida como referente del mundo y como espejo de Dios que cada uno expresa a su manera, de modo que, la sustancia se reconoce en el reflejo de su propia actividad, es decir, es un espejo vivo ${ }^{21}$.

En los siglos XVIII-XIX se detecta la presencia de tres concepciones del espejo: la visión romántica, según la cual los espejos pueden reflejar la trascendencia, abrir el camino a los espacios imaginarios; una concepción realista del espejo que remite al mundo material; y la interpretación racionalista que concibe el espejo como herramienta del conocimiento lógico del mundo y del ser. A nivel pictórico, el espejo se utiliza para introducir el elenco de la presencia ilusoria. Este principio es evidente en los efectos de la auto-contemplación utilizados por Goya de una manera directa en la galería refractaria del palacio de Aranjuez -en el cuadro La familia de Carlos IV-y también en el juego especular que se adopta en Nana y Bar del Folies Bergères, de Édouard Manet, entre otros 22 . En el pensamiento teórico del siglo XIX, la metáfora del espejo recibe una relevancia especial en la obra crítica de Kant y Nietzsche. En el primer caso, el espejo se concibe como reflejo de la mente que, a su vez, remite al reflejo de la realidad. ${ }^{23}$ En el segundo, se hace referencia al espejo que devuelve la imagen de un doble monstruoso y desfigurado, es decir, se trata de la metáfora obstinada, pues la capacidad cognoscitiva del espejo falla y al sujeto se le niega la posibilidad de conocerse y reconocerse fuera de su Fundamento 24 .

En la época contemporánea, con los avances recientes de la reproducción eléctrico-óptica, capaces de mostrar lo que hasta ahora nadie había podido ver -el movimiento, el relieve, el reverso en el derecho -, la imagen adquiere un potencial inédito de recreación y de duplicación. Gracias a los nuevos procedimientos, la representación deja de ser un simple calco de la realidad y libera su estatuto devaluado. Estos avances técnicos en la época contemporánea condicionaron la transformación de las estructuras mentales y esto repercutió en la percepción de la reflectividad. De manera que la indagación sobre el concepto del espejo como símbolo de los procesos cognoscitivos adquirió en la filosofía y en el arte un doble significado. La fan-

21 Cfr. Braun, L., «Speculum fallax», en Bloch, P. A., Schnyder, P. (dir.), Miroirs reflets: esthétiques de la duplicité, Strasbourg, Presses universitaires de Strasbourg, 2003, p. 354.

22 Sobre el concepto del espejo en el arte existen numerosos estudios entre los que destacaremos los siguientes: Hartlaub, C., Die Zauber des Spiegels. Geschichte und Bedeutung des Spiegels in der Kunst, München, R. Piper, 1951, Werness, H., The simbolism of mirrors from ancient times to the present, Mellen Press, New York, 1999, Borel, F., Le peintre et son miroir. Regards indiscrets, Tournai, Le Reanissance du livre, 2002; Pigeaud, J. (dir.), Miroirs: XVe Entretiens de La Garenne Lemot, Rennes Cedex, PU Rennes, 2011, etc.

${ }^{23}$ Cfr. Soto Bruna, M.J., La recomposición del espejo: análisis histórico-filosófico de la idea de expresión, Pamplona, EUNSA, 1995, pp. 203-205.

24 Cfr. Ibidem, pp. 220-231. 
tasía humana penetró en su interior, mientras que el arte, tanto de una manera declarativa, como en su manifestación práctica, vino a evitar la semejanza con el mundo real, tendiendo a una concepción introspectiva, dotada de una dualidad reflexiva. El mundo insólito que cobra existencia en el interior del espejo se convierte en el prisma de la imaginación y del sueño. Sin embargo, llega un momento en el que la voluntad simbólica del reflejo pasa a ser considerada un fracaso. La imagen moviliza demasiados efectos y el espejo, en lugar de anticipar la unidad, se disloca. El espejo renuncia a su función cognoscitiva y el sujeto ya no pretende representarse. La dinámica del reflejo acelera, provocando el quiebre, en tanto que el ser pierde su integridad y se extravía en el laberinto de las identidades.

En este sentido resulta significativo observar cómo abordan este problema los creadores del siglo XX. Un estudio de las representaciones del espejo en el arte, la filosofía y la literatura contemporáneos podría mostrar la recurrencia del espejo vacío, del espejo roto, del espejo que refleja la imagen de un doble y del espejo andrógino.

Melchior-Bonnet en su estudio crítico Historia del espejo sostiene que estas imágenes constituyen el símbolo de la pérdida definitiva de la identidad y de la desvalorización del sujeto ${ }^{25}$. Como la mayoría de los estudiosos que analizan el problema del abandono de la figuración en el siglo XX, Melchior-Bonnet vincula este fenómeno con la incapacidad del artista para reflejar adecuadamente las situaciones y las cosas más simples del mundo real -que se ha vuelto agresivo y engañador-así como las ideas, los elementos y los objetos impuestos por la sociedad. En relación con este aspecto, C. Lewis habla de la amenaza de la abolición del hombre en el mundo moderno. Su argumento principal se centra en el concepto de los valores objetivos y pretende demostrar las consecuencias de la negación de dichos valores, especialmente en el ámbito de la educación. Sus críticas están dirigidas contra la ciega adoración de la tecnología y las ciencias que, en parte, son resultado del poder absoluto de la mente en detrimento de las emociones o la moralidad, lo cual implicaría a su vez el dominio de la fuerza bruta como única autoridad ${ }^{26}$. Esta sensación alarmante del mundo contemporáneo puede apreciarse, por ejemplo, en el cuadro de N. Goncharova El espejo. Navarro de Zuvillaga analiza de la siguiente manera sus características formales:

El lienzo presenta una perspectiva de abajo arriba, con el punto de vista muy bajo, que transforma las verticales en oblicuas que convergen en la parte superior; esta oblicuidad se multiplica en el espejo, ya que éste refleja un rincón del techo y, por tanto, aparecen tres puntos de fuga. La imagen que aparece en el espejo es la esencia del cubismo y en este sentido se podría decir que este cuadro es un homenaje a este movimiento pictóri-

25 Cfr. Melchior-Bonnet 1994, op. cit. (nota 13), pp. 399-408.

26 Cfr. Lewis, C. S., La abolición del hombre, Madrid, Encuentro, 2008, pp. 55-79. 
co, incluso en el caso de que, al mostrar esta esencia en el espejo, nos estuviera diciendo que el cubismo es una ilusión más. ${ }^{27}$

La concepción plástica se caracteriza por una rigidez extrema a la vez que crea la sensación de un movimiento creciente, semejante a una explosión paradójica que destruiría el orden conceptual y las apariencias elaboradas por el hombre. Sin embargo, la aparición de las superficies refractarias vacías o fragmentadas en el arte representativo no se limita a las interpretaciones agresivas que han sido planteadas por los investigadores como símbolo de la cultura contemporánea. En las imágenes y construcciones de los creadores del modernismo plástico, como pueden ser M.Chagall, R.Lichtenstein, J. Pollock, J. Oteiza, R. Magritte o M. Duchamp, entre otros, encontramos ejemplos de una profunda reflexión metafísica y estética acerca del reflejo ausente, que no implica necesariamente un estado de desesperación, destrucción o abolición.

\section{El espejo vacío}

La imagen del espejo que muestra las presencias vacías se encuentra con frecuencia en las exploraciones filosóficas y creaciones artístico-poéticas del siglo XX. Su semántica se determina por la concepción del espejo como símbolo del espacio, metáfora de la cosmovisión e indicador de los valores axiológicos y gnoseológicos.

Empezaremos nuestro estudio de este motivo con la explicación del espejo en su relación simbólica con el espacio. El espejo refleja el espacio de acuerdo con las leyes de la percepción visual, convirtiendo lo interior en lo exterior. Es así como evidencia la capacidad del objeto para reflejar lo que se encuentra fuera del alcance de quien lo contempla, es decir, el espejo tiene poder para amplificar el espacio, "explicarlo"; el espejo se convierte pues en símbolo del espacio.

La superficie transparente posee una doble naturaleza, puesto que de un lado es un médium a través del cual se establece un diálogo entre las apariencias imaginarias soñadas, y de otro, representa la densidad palpable del mundo real. Esta ambigüedad potencial se explica por la capacidad del espejo para crear las imágenes desprovistas de consistencia real. El hombre no se halla físicamente en el lugar donde se encuentra su reflejo, mientras que la superficie especular como objeto sí tiene una existencia material. La compenetración mutua entre estas dos dimensiones, la simultaneidad de lo real y lo ilusorio, acontece en el proceso del acto visual, coincide en la mirada del que está ante el espejo. Indagando sobre la dualidad semántica de las relaciones espaciales, Foucault describe el espejo como una experiencia de

27 Navarro de Zuvillaga 2000, op. cit. (nota 7), p.108. 
naturaleza mixta que participa tanto de los locus heterotópicos (reales) como utópi$\cos$ (ilusorios):

El espejo, a fin de cuentas, es una utopía, pues se trata del espacio vacío de espacio. En el espejo me veo allí donde no estoy, en un espacio irreal que se abre virtualmente tras la superficie, estoy allí, allí donde no estoy, una especie de sombra que me devuelve mi propia visibilidad, que me permite mirarme donde no está más que mi ausencia: utopía del espejo; pero es igualmente una heterotopía, en la medida en que el espejo tiene una existencia real, y en la que produce, en el lugar que ocupo, una especie de efecto de rechazo: como consecuencia del espejo me descubro ausente del lugar porque me contemplo allí. Como consecuencia de esa mirada que de algún modo se dirige a mí, desde el fondo de este espacio virtual en que consiste el otro lado del cristal, me vuelvo hacia mi persona y vuelvo mis ojos hacia mí mismo y tomo cuerpo allí donde estoy; el espejo opera como una heterotopía en el sentido de que me devuelve el lugar que ocupo justo en el instante en que me miro en el cristal, en un tiempo absolutamente real, en relación con el espacio ambiente, y absolutamente irreal, porque resulta forzoso, para aparecer reflejado, comparecer ante ese punto virtual que está allí.28

Las cualidades específicas de las superficies refractarias en su relación con el espacio, repercuten en la formulación de su imagen como metáfora y el símbolo del mundo trascendental. Así, la impenetrabilidad e intangibilidad del espejo como objeto material y el cambio de la ubicuidad de los referentes originales, denotan su potencial de ser el modelo de la existencia virtual, la puerta abierta al infinito o al mundo paralelo. Con respecto a la "percepción utópica" del espacio, resulta interesante la observación de M. Gardner que habla de la actuación ambivalente del espejo sobre el ojo del espectador. Así, éste funciona como una especie de pantalla ilusoria que devuelve la imagen invertida de la realidad:

[...] lo que vemos en la superficie refractaria es la aparición tras el cristal de un mundo que parece tan real como el que está delante y, no obstante, es completamente ilusorio. Si quieres confundir y maravillar a un niño pequeño, haz que se coloque de noche en una habitación oscura frente a una pared ocupada enteramente por un espejo, y facilítale una linterna. Al encenderla frente al espejo, el rayo va derecho hacia la habitación que aparece tras el cristal e ilumina cualquier objeto al que apunte. Este efecto de una habitación duplicada ya es suficientemente misterioso, pero el mismo aumenta, incluso, cuando se cae en la cuenta de que todas las cosas de allí van al revés. Es la misma sala pero no es la misma. ${ }^{29}$

\footnotetext{
28 Foucault, M., «Des espaces autres», Architecture, Mouvement, Continuité 5 (1984), p. 5.

29 Gardner, M., El universo ambidiestro. Simetrías y asimetrías en el cosmos, Barcelona, Labor, 1993, p. 139.
} 
La imagen reflexiva constituye una analogía, similitud de la capacidad humana para percibir el mundo externo no solamente en su extensión espacial, sino también en su dimensión temporal: "el mundo real, el mundo externo a nuestras mentes, no se percibe directamente; vemos sólo lo que nos transmiten nuestras gafas de espacio-tiempo" 30 . De modo que el espacio crea el doble de lo visible y establece una relación discursiva con el tiempo. En cierta medida, se puede decir, que son correlativos de un sistema conceptual común, en tanto que delimitan nuestra percepción del mundo exterior. Ahora bien, si el espejo en el plano literario o representativo funciona como símbolo del espacio, los paradigmas visuales del tiempo son el reloj o el péndulo: "pues el reloj, es el equivalente, en el tiempo, del espejo en el espacio. Tal y como la relación con la imagen en el espejo instituye un cierre y una suerte de introyección del espacio, el reloj es paradójicamente, símbolo y permanencia de introyección del tiempo" 31 .

El reflejo que devuelve la imagen del vacío también puede concebirse como metáfora del universo, al mostrarse inmóvil y ausente de la delimitación espaciotemporal. El mundo se sumerge así en una brumosidad continua que se niega a objetivarse en el ojo del que la contempla. Es lo que Bachelard vino a denominar con el término del "narcisismo cósmico":

En el cristal de las fuentes, un gesto turba las imágenes, un reposo las restituye. El mundo reflejado es la conquista de la calma. Soberbia creación que sólo pide la inacción, que sólo pide una actitud soñadora, en la que veremos el mundo dibujarse tanto mejor cuanto más largo tiempo soñemos inmóviles. Un narcisismo cósmico, [...] un narcisismo velado [...]. Parecía que les falta a los objetos la voluntad de reflejarse. ${ }^{32}$

En las artes plásticas, un ejemplo dilucidatorio sobre las implicaciones del espejo como metáfora de la cosmovisión, símbolo del espacio y contrapartida semántica del tiempo, es el que se advierte en la pintura temprana de Chagall. Este motivo le interesa en tanto que le permite especular acerca del fenómeno de la convergencia del tiempo y del espacio en el módulo transparente de la eternidad, de manera que la imagen especular se convierte para él en la metáfora global del espacio cósmico, que entabla una relación dialogada con el tiempo y su jeroglífico, el reloj. A lo largo de toda su carrera artística, el artista bielorruso se vio fascinado por la meditación sobre los conceptos fundamentales relacionados con la existencia de las unidades cronotópicas ${ }^{33}$. El espejo para Chagall se convierte en una pantalla transparente en la que el mundo puede bambolearse o presentarse en un escorzo paradójico.

\section{Ibidem, p. 143.}

31 Baudrillard, J., El sistema de los objetos, México, Siglo XXI,1968, p. 24.

32 Bachelard, G., El agua y los sueños: ensayo sobre la imaginación de la materia, Méjico, Fondo de Cultura Económica, 1994 pp. 45-47.

33 El término cronotopo (del griego: kronos = tiempo y topos $=$ espacio, lugar) fue acuñado por Michail Bajtín en Las formas del tiempo y del cronotopo en la novela. Por dicho concepto se entien- 
En 1915, a la vuelta de París, Chagall pinta una de sus pequeñas obras maestras que determinaron las características de su arte maduro y, en cierta medida, predestinaron el desarrollo del arte pictórico en el siglo XX, El Espejo. En este cuadro encontramos la unión de las impresiones no olvidadas y de nuevo penetrantemente vividas de la realidad vitebskiana, de las lecciones parisinas y de las cuestiones eternas: el transcurso del tiempo, la semántica del espacio, la interrelación de micro y macrocosmos y los sentimientos humanos. Por otro lado, se pone de relieve la dicotomía existencial alegría/dolor contemplada a través del prisma del mito, concebido en su dimensión sublimada o ritual e ingenua.

El cuadro es prosaico y fantástico a la vez: la mesa cubierta por el mantel blanco, la silla vienesa, la figurita de la mujer dormida y el espejo con su marco dorado en el que se refleja un quinqué. Nada más. Pero la inversión de las proporciones y el mundo que se balancea crean la sensación de un sueño articulado, donde las cosas adquieren una nueva belleza y un sentido desconocido, fatídico y temible.

de la conexión entre las relaciones temporales y espaciales, asimiladas en el ámbito artístico y literario. El cronotopo es la unidad espacio-tiempo, indisoluble y de carácter formal expresivo. Es un discurrir del tiempo de la cuarta dimensión, densificado en el espacio y de éste en aquel donde ambos se interceptan y se vuelven visibles al espectador y apreciables desde el punto de vista estético. En una misma obra literaria o artística pueden coexistir distintos cronotopos que se articulan y relacionan en la trama narrativa creando una atmósfera especial y un determinado efecto. El concepto de cronotopo es utilizado por Bajtín solamente en el contexto literario. Sin embargo, sus descripciones están cargadas de unos matices más genéricos. "En el cronotopo artístico y literario, indicadores espaciales y temporales están fusionados en un conjunto concreto y bien elaborado. El tiempo engorda, adquiere carne, se hace artísticamente visible, de la misma manera el espacio responde a los movimientos de tiempo, trama e historia", cfr. Bakhtin, M., «Forms of time and of the chronotope in the novel», en Bakhtin, M., The dialogical imagination: Four essays by M. Bakhtin, Austin, Michail Holquist Ediciones, 1981, p. 84. Definida en semejantes términos, la categoría del cronotopo puede extenderse al ámbito de las artes plásticas. El cronotopo puede ayudar a ilustrar los aspectos fundamentales del arte pictórico. El concepto de cronotopo permite describir la interdependencia del tiempo y espacio artísticos en una obra de arte. Jay Ladin en su artículo "Fleshing out the chronotope" hace una observación acerca de la utilidad de la categoría de cronotopo para la investigación de los ámbitos paralingüísticos. En este sentido, la aplicación del cronotopo puede resultar plausible, al menos, en dos aspectos. Primero, el cronotopo es un buen instrumento crítico que se encuentra aún en estado germinal. Éste podría explicarse más adecuadamente y recibir un desarrollo posterior en tanto se aplique a la interpretación de las artes plásticas, ya que el concepto en sí mismo tiene una proyección visual. Segundo, el cronotopo ayuda a comprender mejor la organización estructural de las artes plásticas, cfr. Ladin, J., «Fleshing out the chronotope», en Emerson, C. (dir.), Critical essays on Mikhail Bakhtin, New York, G. K. Hal, 1998, p. 228. En el presente estudio vamos a utilizar el término cronotopo para explicar las relaciones entre el espacio y el tiempo pictóricos en un sistema visual, sea el cuadro, la escultura o la instalación. La posibilidad de entender el cronotopo como categoría estética en el más amplio sentido, tiene su origen en el método que utiliza el mismo Bajtín para el análisis de las obras literarias. Así, en La cultura popular en la Edad Media y en el Renacimiento. El contexto de François Rabelais, el filólogo ruso tiene en cuenta el cronotopo específicamente en conexión con las imágenes de Rabelais. Las nociones de tiempo y del espacio se fusionan en la interpretación del cuerpo humano grotesco. 
Esta equiparación de lo no equiparable carece del naturalismo ilusorio y estereoscópico de las imágenes del subconsciente que pronto aparecerán en la pintura surrealista: los objetos de Chagall son más bien fabulosos, ficticios, su mensaje está destinado a las "alturas" y no a los "sótanos" de los sentimientos y de los pensamientos.

Todo en el cuadro está compuesto de la sustancia del arte, no es una falsificación de las cosas o su ilusión, sino fórmulas plásticas dotadas de alma. Su combinación no parece antinatural, como sucede en los sueños; la conciencia no las rechaza, sino, al contrario, encuentra en ellas las uniones armónicas perdidas en el tiempo cotidiano. El modesto quinqué colocado sobre la mesa vive el momento de la transfiguración. Su base ejecutada en el estilo del ampiro (como si se tratase de un recuerdo infantil o de un sueño) se convierte en una monumental columna. Tanto el sueño, como el espejo, aumentan esta lámpara mágica, elevando su dolor como si fuera una lumbrera. El objeto adquiere una triple dimensión: una simple lámpara que pretende ser la representación del lujo campesino que ilumina una habitación común y corriente, la "lumbrera" que ilumina el aposento y, finalmente, la fuente cósmica de la luz que lucha contra la tiniebla del sueño pegadizo y que la vence. La eternidad golpea la realidad cotidiana.

En la simbología aparentemente ingenua del cuadro, se funda un programa genético que guarda una extraña conexión con aquella lámpara-sol que estalla antes de la llegada de la tiniebla centenaria del Guernica de Picasso. Esta analogía resulta todavía más evidente cuando observamos que en el mundo de Chagall la lámpara se balancea en el titubeante espejo de la conciencia sumergida en el sueño o, quizás, despertándose.

Picasso representa una explosión trágica y la tiniebla que la sigue, mientras que en Chagall asistimos a una lenta brumosidad, "regreso" de la luz. Dicho efecto se consigue mediante el hecho de que la lámpara y su luz se nublan, se "incineran" en su gama lila-morado con los reflejos pálidamente esmeraldinos que desmerecen la gaitería del marco y la doradura del espejo. Además, la lámpara y la luz no son reales, sino que están reflejadas en la triste profundidad del cristal especular, la nebulosa trascendencia que tanto contrasta con el vulgar brillo del engarce.

Hay que decir que esta ramplonería no penetra en el "material del arte", cuya única función es ser el signo de la realidad en el mundo ficticio. "El sueño de la razón" no "produce monstruos" 34 en este caso. Al contrario, si los objetos simples llegan a provocar miedo o a inquietar al espectador, se debe exclusivamente a su capacidad aclaratoria, superior a la del mundo real, la mismidad, la asociatividad exuberante.

\footnotetext{
34 Aludimos al grabado de Goya "El sueño de la razón produce monstruos" que forma parte del conjunto gráfico titulado Los caprichos.
} 
La magia pictórica de Chagall juega un papel decisivo en la creación de esta imagen visionaria. Las olas concéntricas del lila y el verde, que salen de la lámpara, parecen estremecerla, y estremecer también al espejo, a las paredes y al triángulo estridentemente amarillo situado en el ángulo superior del cuadro. Todo se mueve, como en un péndulo, al ritmo simultáneamente adormecedor y catastróficamente acelerado (el efecto del espacio destruyéndose). Al mismo tiempo, todo permanece abierto a la conciencia liberada: las cosas se vuelven antropomórficas, se hacen más grandes y más bellas, como en el sueño y la fantasía. El hombre se siente pequeño, las relaciones de las proporciones se ven paradójicamente transformadas. Este rasgo es inherente a la concepción artística de Chagall: la escala de los objetos en sus cuadros viene determinada por su relevancia semántica en el momento concreto de la representación.

El gouache Reloj, pintado en 1914, constituye un análogo directo del Espejo. Los elementos que configuran la composición son similares, aunque el universo reflejado en el espejo es reemplazado aquí por el reloj procedente de la casa natal de Chagall. El tiempo se ha materializado aquí en el péndulo gigantesco, cuyo ritmo parece marcar el transcurso de la vida humana. En cambio, en El Espejo, el movimiento del péndulo forma parte de la superficie pictórica, el tiempo es invisible, pero tangible.

Las formas especulares inducen a los artistas a reflexionar sobre la figura ausente; esto ha dado paso a los experimentos formales conducentes a la abstracción. Así, Roy Lichtenstein utiliza el motivo del espejo en una serie visual que lleva el mismo título ${ }^{35}$, para crear unas imágenes de carácter minimalista y despojadas de realidad. Efectivamente, J. Hendrickson propone que si el título no revelara a quien contempla el cuadro el significado de la imagen, el espectador no reconocería el objeto representado. Los espejos parecen brindarle una oportunidad de guiar la pintura en esta dirección, sin abandonar por completo la figuración 36 .

La tela se corresponde con la imagen, de manera que la pintura aparenta ser ella misma, es decir que la representación no remite al modelo, porque la superficie especular no es transparente, sino que se colorea con los tonos que le concede el artista en su juego voluntario con la materia. Como muchos espejos reales, estas obras pueden ser redondas, elípticas o rectangulares. En conjunto, se tiende a una paleta reducida, con el predominio de un solo pigmento, aunque puede haber diferentes sectores pictóricos que ocupen grandes áreas de la tela. Puntos bendéi aplicados en secciones de direcciones, gradaciones y densidades variables señalan los reflejos y sombras.

35 Sobre el motivo del espejo en Roy Lichtenstein, cfr. Cowart, J. (dir.), De principio a fin: Roy Lichtenstein, Madrid,Editorial de Arte y Ciencia, 2007, pp. 21-23.

36 Cfr. Hendrickson, J., Roy Lichtenstein, Madrid, Taschen, 2001, p. 75. 
La cuestión acerca de la existencia de la similitud entre el objeto real y la superficie refractaria se encuentra en el centro de las preocupaciones conceptuales de Lichtenstein. Cuando se contempla algo en el espejo, se produce la situación inversa: este fenómeno y el frío efecto plateado separan al objeto o cara real de su verdadero yo. El artista niega la experiencia subjetiva de un contemplador de su arte mediante un espejo vacío y un espacio vacío. Ninguna de las aproximadamente cuarenta pinturas refleja una sola presencia viva. En una obra titulada Autorretrato, de 1978, Lichtenstein coloca un espejo vacío en el lugar de la cabeza, mientras que una camiseta blanca representa la parte superior del cuerpo. Esta imagen puede interpretarse desde una doble perspectiva. Por un lado, la transformación del rostro en un espejo vacío puede aludir al rechazo de los poderes omnipotentes del hombre en cuanto al conocimiento del yo, propios de la visión renacentista. Por otro lado, el problema que se pone de relieve en el cuadro concierne al tema del homo faber, es decir, del hombre capaz de ver sus limitaciones y sus posibilidades, que es lo suficientemente atrevido como para enfrentarse a su propia identidad y reconstruirla a partir de los componentes que están a su disposición, para lo cual es necesario limpiar o abandonar la imagen anterior de sí mismo. Este mismo motivo aparece en la obra de Herman Hesse, El Lobo estepario. Al haberse encontrado en el teatro mágico de la galería especular de su alma, el protagonista de la novela, Harry Haller, entra en una de las puertas cristalinas que tiene la inscripción "Instrucciones para la reconstrucción de la personalidad. Resultado garantizado". Allí le espera un guía espiritual que le advierte que para construir un nuevo "yo" es necesario abandonar la personalidad anterior mirándose en el espejo. Como resultado de este acto de autodestrucción catártica, Harry obtiene una imagen vacía, a partir de la cual puede empezar a configurar la personalidad deseada ${ }^{37}$. Este fenómeno ha sido interpretado de la siguiente manera por Lacan; el psicoanalista francés observa que el hombre suele identificarse con una serie de máscaras que operan mediante un conjunto de confusiones de tipo imaginario. El sujeto se dirige, a su vez, a los objetos en una relación ficticia y, a partir de ahí, construye un yo alienado. El motivo es que olvida que quien lo dirige a él y lo constituye es "el otro absoluto" del orden simbólico (la sociedad y la cultura) ${ }^{38}$.

El espejo vacío como arquetipo del universo y de las relaciones del arte con la técnica, es otro rumbo en la reflexión metafísica de los artistas contemporáneos. Existe una pieza -se trata de una instalación- que podría considerarse una especie

\footnotetext{
37 Cfr. Hesse, H., El lobo estepario, Buenos Aires, Santiago Rueda Editor, 1959, pp. 199-203. Para el motivo del espejo en la obra de H. Hesse, cfr. Mattiussi, L., Fictions de l'ipseite: essai sur l'invention narrative de soi (Beckett, Hesse, Kafka, Musil, Proust, Woolf), Geneve, Droz, 2002, pp. 158-161.

38 Cfr. Lacan, J., «Le Stade du miroir comme formateur de la fonction du je», Revue française de psychanalyse, 4 (1949), pp. 449-455; sobre la teoría de Lacan, cfr. J. P. Fages, Para comprender a Lacan, Buenas Aires, Amorrortu, 1973.
} 
de símbolo: La ascensión en la memoria de C. Parmiggiani. Muy esquemáticamente, consiste en una especie de espejo oscuro en el que se inscribe la imagen del cielo estrellado, es posible arribar a éste gracias a una escalera que se apoya sobre una tela virgen. Parmiggiani concibe el espejo como una visualización de los símbolos trascendentales, un abismo, abierto al infinito, al que sólo se puede acceder mediante la escalera de la imaginación. La escalera es el instrumento del artista; vínculo entre el cielo y la tierra. El principio de la escalera que posee un doble movimiento hacia arriba, pero también hacia abajo o de vuelta, ha quedado plasmado en la tela. Al decir estrellas e infinito estamos hablando de algo que traspasa los límites de la existencia humana y penetra en el espacio cósmico y celestial 39 .

En esta misma dirección, aunque a nivel más formal, pueden entenderse las estructuras transparentes de Oteiza. Las indagaciones estéticas del escultor vasco le han llevado a trasponer una pintura plana a la espacialidad del muro sirviéndose de unas maquetas de vidrio superpuestas con unidades de trozos negros de forma irregular que presentan un claro parentesco con el arte de Malévich. Esta creación -simbiosis entre el espacio bidimensional y tridimensional- cobra vida al introducirse el juego de la luz. La interacción del transparente lumínico y la realidad fragmentaria condicionan una visión del vacío como esencia metafísica del espacio. La proyección de la luz en la superficie cristalina crea las fisuras en la estructura material y visible del mundo real. Ahora bien, este efecto perceptivo, a nivel arquetípico, puede concebirse como una ventana a otro mundo, apertura a la dimensión trascendental ${ }^{40}$ :

Con una luz artificial de lado y con el sol alto, el resultado es impresionante [...] el aire se ha convertido en luz. El vacío, en cuerpo espacial desocupado y respirable por las formas. Aquí una forma puede ensayar un giro completo, avanza, se traslada, retrocede, se pone de perfil y se vuelve. Proyecta y recibe sombra. La sombra crece o disminuye, se hace más intensa o se completa con una misteriosa zona de penumbra. La penumbra se agujerea de luz. 41

A continuación, Oteiza reflexiona sobre las cualidades del cristal que él denomina el "Muro cristalino", para crear la multitud infinita de las hiperrealidades espaciales: "este corte en la luz que es el vidrio plano que corresponde al plano físi-

\footnotetext{
39 Sobre Claudio Parmiggiani, cfr. Amic, S. (dir.), Claudio Parmiggiani, ouvrage collectif, Arles, Actes Sud, 2003.

40 Sobre las superficies cristalinas como aperturas a la infinitud, cfr. Levin, U., "Espejo como objeto potencial semiótico", p, 11, en Espejo. Semiótica del espejo. Los procedimientos de los sistemas de signos, Tartu, Publicaciones de la Universidad de Tartu, 1988, pp.6-25.

41 Oteiza, J., «Escultura dinámica», en El arte abstracto y sus problemas, Madrid, Ediciones cultura hispánica, 1956, cit. por Rosales, A., Apalategi, J. (eds.), Jorge Oteiza: creador integral /, Pamplona, Universidad Pública de Navarra, 1999, pp. 37-38.
} 
co del muro, es una placa desocupada, transparente y alerta a todo el acontecer, dentro de un campo variable, del que no es más que una parte estratégica y sensible que opera por revelación [...]"42.

En su aspecto axiológico, el espejo funciona como emblema de nuestra capacidad para reflejar las profundidades interiores, es una herramienta del conocimiento de la verdad. La imparcialidad y la espontaneidad del reflejo especular hacen que éste se convierta en modelo de la verdad. La imagen especular funciona como "la designación rígida" del objeto reflejado, en tanto que captura exactamente lo que aparece en ella 43 . Es por ello por lo que el espejo figura como metáfora de los valores morales y de la autenticidad de la información transmitida. En esta dimensión semántica aparece este objeto en la novela Siete pecados mortales, de M. Pavic, cuyo argumento narrativo se organiza en torno al motivo del espejo ahuecado. El protagonista de una de las historias de la novela, entrecruzadas semánticamente, es atraído por él y se mira en él, pero en lugar de un reflejo suyo, ve la oscuridad, la realidad metafísica. Otra implicación ontológica del espejo reside en su visión como metáfora de la verdad y en la capacidad de la mente productiva, espiritualmente activa. De manera que, para poder orientarse en los laberintos simbólicos de la Historia, habría que entrar en el diálogo con el espejo. La única posibilidad de comprobar su autenticidad para el lector, es decir, su capacidad para convertirse en el co-creador de la obra, de participar en su formación, es contemplar su reflejo en la oscuridad de la superficie cristalina: "- No lleves a mi historia a ningún idiota de tu facultad. -Bueno, eso se resuelve fácil. Cuando lo lleve, deja que Ingirina se ponga enfrente del espejo ahuecado y mire atentamente si nuestro huésped queda reflejado en él. Si ella no consigue ver su rostro allí esto va a significar que éste es verdadero, puesto que al lector no se le puede ver en los espejos de los libros como es el nuestro" 44 .

En la obra titulada Prohibida reproducción, de Magritte, la imagen especular se niega a representar la cara. Con esta inversión de la capacidad refractaria, el pintor nos expresa la imposibilidad del ser humano para conocerse hasta las últimas consecuencias; una parte nuestra siempre permanece oculta en la libido individual o colectiva. El doble que se nos presenta en el espejo, es decir, que se proyecta en nuestra conciencia, es el vacío, la parte superficial de nuestro ser.

La reflexión sobre el espejo vacío como metáfora de la creación artística es inherente a la visión estética del siglo XX. La contigüidad del espejo y el arte se determina por el hecho de que ambos crean un mundo similar al reflejado, pero que no les es idéntico, es el mundo ilusorio, la realidad imaginaria. El intercambio de

\footnotetext{
42 Ibidem, p. 38.

43 Cfr. Eco, U., Semiotics and the Philosophy of Language, Bloomington, Indiana university press, 1984, pp. 207-208.

44 Pavic, M., Siete pecados mortales, San Petersburgo, Ánfora, 2010, p. 124.
} 
los lados en el reflejo especular se corresponde con la transformación creativa de la realidad, de acuerdo con las leyes artísticas, cuyo producto está constituido por el cuadro u obra literaria. Como ejemplo, presentaremos la obra de Rilke. En uno de los sonetos que forman parte del ciclo Sonetos de Orfeo, el poeta alude al concepto del vacío como el locus ideal donde habitan la poesía y sus fuentes. En palabras de M. Blanchot, él hace de la poesía una especie de médium de comunicación con la vaciedad, o "establece la semejanza de la poesía con el enturbiamiento de la conciencia"45. En efecto, el espejo tiene capacidad para sumergirle a uno en un estado de suspensión existencial que puede igualarse a la sensación de vacío: "Espejos, nadie en rigor dijo nunca, / en qué esencialmente consistís. / Como los huecos de una urdimbre /colmados sois por las pausas. / [...]. Os llenáis a veces de pinturas. / Unas parecen haber logrado entrar, / a otras las rechazáis tímidamente" 46.

La poesía, como el espejo, reconstituye la actividad simbólica y el tema del poema -el unicornio que se deleita contemplando su reflejo-no se limita a las sensaciones individuales narcisistas, sino que se convierte en la percepción de las latencias diversificadas del ser. La nada del vacío es también el todo de las posibilidades infinitas ${ }^{47}$.

\section{Espejos rotos}

Otro grupo de imágenes especulares, halladas con frecuencia en el arte contemporáneo, están relacionadas con la representación fragmentada de la realidad. Se trata del fenómeno del espejo roto que ha sido vinculado a la sensación del vacío, del horror y de la soledad. Los fragmentos del cristal simbolizan la pérdida de las raíces, la inestabilidad de la similitud y de la identidad, la fragilidad de la personalidad, los fantasmas de la penetración y absorción, el espacio laberíntico, el miedo a la impotencia y a la desintegración.

La teoría de la expresión, enunciada por el filósofo italiano G. Colli en su Filosofia dell'espressione, es paradigmática, puesto que el motivo del espejo roto se utiliza aquí para demostrar que la pretensión de un conocimiento último del mundo inserta al hombre en un callejón sin salida pues, en última instancia, se le niega la posibilidad de acceder al conocimiento de la verdad:

El mundo es la imagen de un dios despedazado, reflejado en el espejo: por ello, mera apariencia e ilusión- pues la figura que se muestra a través del espejo no es la de dios-; laberinto de espejos destinado a repetirse eternamente, pura contingencia. Al final de

\footnotetext{
45 Blanchot, M., L'Espace littéraire, Paris, Gallimard, 1955, p. 166.

46 Rilke, R. M., Sonetos a Orfeo, Madrid, Rialp, 1954, pp. 96-97.

47 Cfr.Melchior-Bonnet 1994, op. cit. (nota 13), p. 396.
} 
esta serie de expresiones, reflejos o manifestaciones del dios, el hombre que quiere comprender el universo sólo halla opacidad y silencio, pues el dios a quién deberían remitir las imágenes se halla-despedazado y desfigurado-dentro de ellas. ${ }^{48}$

La fragmentariedad del ser en la imagen reflejada puede valorarse también como modelo de los procesos gnoseológicos y como medio que permite exteriorizar la estructura metafísica de la identidad humana. Es así como lo hallamos en el pensamiento de M. Merleau-Ponty: "el fantasma del espejo arrastrado fuera de mi carne, y por lo tanto invisible, que está en mi cuerpo, adquiere inmediatamente la capacidad de conferir una mayor visibilidad a otros cuerpos presentes en mí. A partir de ese momento, mi cuerpo puede contener segmentos tomados de los cuerpos de otras personas" 49 . Por lo tanto, de acuerdo con Merleau-Ponty, el espejo es una herramienta única para detectar la circulación de los cuerpos videntes en los visibles, de la transformación del yo en los otros y de los otros en mí. El proceso de introspección, complementada y estrechamente asociada con las limitaciones sensoriales de la percepción, es el fundamento del autoconocimiento, el propio, y el del universo, en el sentido más amplio.

La transformación de la percepción de las capacidades cognoscitivas del ser, identificadas en el pensamiento filosófico y estético de la edad contemporánea, está condicionada por los avances de las ciencias y del psicoanálisis. En la confrontación diaria del hombre con los demás y consigo mismo, con la naturaleza y sus símbolos, el intelecto produce multitud de imágenes ilusorias que no son otra cosa que proyecciones de la conciencia humana, sus reflejos mentales. Marie-Louise von Franz destaca cuatro tipos de relaciones que tienen como base la metáfora del espejo: el reflejo del ego por su yo, el reflejo del yo por el ego, el reflejo de la realidad por el inconsciente colectivo y el posible reflejo del inconsciente colectivo en las situaciones cotidianas ${ }^{50}$. De modo que, el ser humano ya no es considerado como una unidad constante e íntegra, sino que es percibido como multiplicidad del yo que empieza a funcionar cuando se agrupa de una manera determinada. Así, la personalidad humana se construye a partir de la metamorfosis que incluye cuatro tópicas: ello, ego, yo y superego. El funcionamiento de la personalidad humana depende del "juego dinámico" entre estos elementos intrínsecos. Comenta G. Marcuse: "el superego construye y protege la unidad del ego, asegura su desarrollo bajo el principio de realidad, y trabaja así al servicio de Eros. Sin embargo, el superego consigue estos objetivos dirigiendo al ego en contra de su ello, volviendo una parte de los impulsos destructivos contra una parte de la personalidad" 51 .

\footnotetext{
48 Soto Bruna 1995, op. cit. (nota 23), p. 233.

49 Merleau-Ponty, M., L'oeil et l'esprit, Paris, Gallimard, 1964, pp. 33-34.

50 Cfr. Von Franz, M-L., Projection and re-collection in jungian psicology. Reflection of the soul, London, Open Court, 1980, pp. 186-189.

51 Marcuse, H., Eros y civilización, Barcelona, Ariel, 1981, pp. 61-62.
} 
La voluntad de una reestructuración global de las relaciones con el entorno y con su individualidad es evidente en el fenómeno del narcisismo. Como Selma de la Hoz deduce de la teoría de Caruso: "el amor propio es un intento defensivo que presenta la tendencia a volver al punto de partida donde la libido todavía no estaba separada de las pulsiones del ego, para posibilitar una nueva formación, tanto del propio ego como de las relaciones con el mundo" 52 .

Por otro lado, la superficie brillante y perfecta que refracta la imagen ilusoria disimula la verdad, creando las telarañas especulares que impiden ver la verdad existencial. Y el único camino para salvarse, para encontrar la propia identidad, hablando metafóricamente, es romper este laberinto de las apariencias visuales.

En este sentido es excepcional la novela que hemos mencionado previamente, El lobo estepario. El protagonista de la narración, Harry Haller, entra en el teatro mágico de su propia alma, constituida por los espejos que reflejan las apariencias de su personalidad. Al verse en un "espejo verdadero", Harry se da cuenta de la multiplicidad de su yo, al convertirse en el testigo de la fragmentación de su identidad en la infinitud de las figuras y los pedazos de estas figuras ${ }^{53}$.

En el arte pictórico, el principio del espejo roto es evidente en las composiciones cubistas que convierten el espacio homogéneo en una serie de fragmentos discernidos. Si observamos con profunda atención veremos en las temibles fantasmagorías de Picasso, empezando por Las señoritas de Aviñón y terminando por Guernica, el mismo efecto del "espejo roto", el mal espejo de los trolleys de Anderson o los efectos de rompecabezas de la óptica dinámica computarizada. Como el reflejo en un espejo roto, fondo y figura, interior y exterior, dejan de ser elementos diferenciados, y la reconstrucción de ese complicado puzzle queda a merced de la mirada del espectador. ${ }^{54}$ Este efecto se consigue mediante el método de la articulación de los diversos puntos de vista en una unidad pictórica.

La simultaneidad de la percepción de los elementos representados contribuye a que el espacio tridimensional ficticio, en lugar de facilitar las cosas, se convierta en una traba; pronto le sucede lo mismo al ojo del espectador: es imposible combinar multitud de puntos de vista y, por lo tanto, es improcedente concebir cada parte del objeto como referente de un punto de vista. De ahí que el plano pictórico se convierta en el campo experimental del análisis y la disección. Los retratos y los autorretratos, las formas perfectas del lenguaje mimético de las épocas anteriores, sufren

\footnotetext{
52 Selma de la Hoz, J. V., Creación artística e identidad personal: cultura, psicoanálisis y conceptos de narcisismo en el siglo XX, Valencia, Institució Alfons El Magnànim, Diputació de Valencia, 2001, pp. 71-72.

53 Hesse 1959, op. cit. (nota 37), p. 187.

54 Este mismo planteamiento se aprecia en la exposición El espejo y la máscara: el retrato en el siglo de Picasso en la que la representación cubista se concibe como la imagen reflejada en el espejo roto, cfr. Alarcó, P. (dir.), El espejo y la máscara: el retrato en el siglo de Picasso, Catálogo de la exposición, Madrid, Museo Thyssen-Bornemisza-Fundación caja Madrid, 2007, pp. 143-161.
} 
una transformación en la iconoesfera del artista del cubismo. La figura humana se trocea en miles de pedazos irregulares, la superficie pictórica se descompone dando paso a una imagen fragmentaria que tiende a abolir la distinción entre el retratado y el fondo en el que se encuentra. Como ejemplo, podríamos mencionar tres retratos de Picasso realizados en la década de1910, los de Wilhelm Uhde, Ambroise Vollard y Daniel-Henry Kanweiler ${ }^{55}$, que sugieren la desintegración de la imagen del hombre en una serie de fragmentos transparentes que en su aspecto recuerdan el efecto del cristal roto. La luz y el color desempeñan un papel singular en la plasmación de estos reflejos discernidos. La progresiva monocromía reduce los contrastes cromáticos, convirtiendo el espacio pictórico en una superficie transparente que se multiplica. La configuración analítica de la luz no elimina por completo los valores plásticos del fondo y la figura, creando una simbiosis cronotópica. La disposición centralizada de los motivos tiende a consolidar las diferencias entre el personaje principal y el ambiente que le rodea, contribuyendo a una ambigüedad semántica.

Otra variante del espejo roto puede hallarse en la obra de Magritte, en la que la transferencia de las apariencias reales en el espacio cristalino se convierte en un recurso pictórico que permite abrir las ventanas a un mundo ilusorio. Este motivo aparece en algunos de sus lienzos de principios de los treinta, como La llave de los campos, 1936. En este cuadro, varios pedazos de cristal roto, que corresponden a diferentes fragmentos de la vista exterior, han caído dentro de la habitación y están reagrupándose para configurar un paisaje paralelo y alternativo al del exterior. Magritte volvió a emplear el mismo recurso en el cuadro Los dominios de Arnheim, en 1949. La composición se divide en dos partes: la interior y la exterior. El juego de las apariencias viene a demostrar la relatividad de la visión humana que pretende crear un mundo sólido y encerrado en sí mismo, mientras que la vida, como el espíritu, es más compleja y se caracteriza por "tener apertura, actividad creadora y posesión de los fines" 56 . La misión de la imaginación poética consiste en romper este "muro cristalino sin salida", desprenderse de la materia carente de la simultaneidad y descubrir la ambigüedad del universo y del ser humano.

Por último, señalaremos la manifestación lúdica del espejo roto en el arte contemporáneo ${ }^{57}$. En este sentido, resulta paradigmática la figura de Duchamp. Este Proteo del surrealismo se comporta como un jugador cuando continuamente bordea o traspasa los límites de lo que consideramos una obra plástica. Así lo expresa en las siguientes palabras: "yo quería huir del aspecto físico de la pintura. Estaba

\footnotetext{
55 Sobre estos dos retratos, cfr. Bozal, V., Estudios de arte contemporáneo. 1, La mirada de Cézanne, la indiferencia de Manet, la ironía de Klee y otros temas de arte contemporáneo, Boadilla del Monte (Madrid), A. Machado Libros, 2006, pp. 82-83.

56 Alvira, R., Reivindicación de la voluntad, Pamplona, EUNSA, 1988, p. 202.

57 Sobre el elemento lúdico en el arte contemporáneo, cfr. Gutiérrez Párraga, M. T., La significación del juego en el arte moderno y sus implicaciones en la educación artística, Madrid, Universidad Complutense de Madrid, 2004, pp. 113-231.
} 
mucho más interesado en aplicar ideas lúdicas a la pintura [...].Según mi parecer Courbet, ya en el siglo XIX había subrayado este carácter físico. En cambio, yo estaba interesado en las ideas, no tan solo en los productos visuales. Quería volver a poner la pintura al servicio de la mente" 58 .

La orientación intelectual del arte, evidente en este texto, recibe un desarrollo importante en sus experimentos con las superficies cristalinas. En la instalación Le grand verre, Duchamp utiliza el principio de la desaparición del soporte tradicional gracias al cual el cuadro se convierte en algo transparente a través del cual se puede mirar como si de una ventana se tratase. Cuando el cristal se rompió en 1926, el artista lo aceptó como parte integrante de la obra: "la idea de transparencia resulta cómoda para no fijar las cosas. Si a ustedes les gustan los árboles y los negros, los ponen detrás. Esto añade una tercera dimensión artificial, pero muy seria"59.

La noción ontológica del juego está relacionada con la imagen especular en tanto que tiende a autorrepresentarse en el proceso del movimiento constante y reiterativo, potenciado por sus propias fuerzas. En otras palabras, "[...] el juego aparece como automovimiento que no tiende a un fin o a una meta, sino al movimiento en cuanto a movimiento, que indica el fenómeno de la autorrepresentación del ser viviente" 60 .

Esta implicación de lo lúdico se manifiesta también en el proyecto de Duchamp. Así, la instalación del vidrio no puede pensarse como algo independiente, sino como la parte íntegra del juego de las apariencias que enuncia la idea del retorno y del movimiento continuos. En su artículo «Retorno espejado en la obra de Marcel Duchamp», Lourdes Peñaranda afirma: “[...] en su reafirmación circulatoria y por su transparencia, el vidrio se extiende a través de sus sombras sobre paredes y pisos o cualquier elemento a su alrededor; además nos incluye como espectadores en su contexto, convirtiéndonos (tanto al espectador como al contexto) en ready-mades recíprocos en continuo cambio"61.

El espacio especular de la instalación se concibe como el fundamento de un juego intelectual. En cierta medida, esta construcción puede interpretarse como el "juego de abalorios" de los residentes de Castalia, el país del espíritu, cuyo objetivo es participar en el acto de la creación meditativa e intelectual que consiste en la sincronización de los conocimientos elevados, conceptos y obras de arte, contenidos y resultados de las investigaciones científicas, valores culturales y percepciones intuitivas. En palabras de Hesse, "tal instrumento cabría reproducirlo en el juego de todo el dintorno espiritual del mundo"62.

\footnotetext{
58 M. Duchamp citado por Spector, J. J., Arte y escritura surrealistas, (1919-1939) el oro de tiempo, Madrid, Síntesis, S. A., 2003, p. 385.

59 Duchamp citado por Cirlot, L., Las claves del dadaísmo, Barcleona, Planeta, 1990, p. 40.

60 Gadamer, H. G., La actualidad de lo bello, Barcelona, Paidós, p. 67.

61 Peñaranda, L., «Retorno espejado en la obra de Marcel Duchamp», Argos Vol. 2549 (2008), p.10

62 Hesse, H., El juego de los abalorios, Madrid, Alianza, 2001, p. 17.
} 
A semejanza de este "instrumento universal", Le grand verre, según la idea de Duchamp, tendría que ser una construcción compleja, compuesta por cristal y otros mecanismos o, más bien, modelos, arquetipos de estos mecanismos, con un profundo significado ontológico y sinsémico ${ }^{63}$. La descripción e inventario de los mismos contenidos en la Boîte Verte forma la parte vital del proyecto y funciona como un manual apropiado de instrucciones en el que Duchamp juega con la obra y con el espectador. Gracias a este doble funcionamiento, la estructura de la obra permanece abierta, ya que es el espectador quien en el acto contemplativo descubre, da la vida y recrea los contenidos estéticos y filosóficos implícitos, latentes en la obra.

\section{El espejo y el doble}

El espejo se vincula a otro motivo de gran importancia en el arte, la narrativa y la estética, me refiero al concepto del doble. Siendo fruto de la época romántica, éste se repitió como un eco y recibió nueva vida en la literatura rusa del siglo XIX, de Gogol a Dostoievsky, para pasar luego al siglo XX, influyendo significativamente en el arte plástico. Según la interpretación de Otto Rank, este motivo está íntimamente ligado al mito de Narciso. La semántica de este mitograma y la del doble son superponibles. Así, las nociones de muerte y misterio, implicados en el reflejo duplicado, dialogan con el fenómeno de la auto-admiración: "el motivo del doble, cuyo significado primario en el folclore se refiere al alma y a la muerte, no es ajeno a la verdadera esencia del narcisismo. Las tradiciones mitológicas que hemos mencionado, según las cuales el mundo sería una creación de la auto-admiración a un dios en el espejo $[\ldots]^{\prime \prime} 64$.

Con respecto al problema del doble y de su tópico, el amor a sí mismo, las teorías psicoanalíticas hablan de la creación, por parte del ego, de un reflejo idéntico a partir de una auto-representación proyectada a una persona imaginaria que se aproxima en la mayor medida posible a ellos. Como indica Selma de la Hoz a partir del análisis del libro de Louis Corman, Narcisismo y frustración de amor (1975), este repliegue psíquico "no se limita a la vida interior del sujeto, sino que llega a inter-

\footnotetext{
${ }^{63} \mathrm{El}$ término de la sinsemiya alude al método de la organización artística que presupone la integración en una obra de arte de los conceptos del conjunto de los valores intelectuales y culturales (para la construcción de las series asociativas individuales y la creación de las pluralidades perceptivas). La cita manifiesta o disimulada es el indicio de la intertextualidad en la civilización contemporánea. Mediante la inclusión en la obra, por parte del autor, de las citas, códigos, signos o alegorías, tomadas de los distintos campos de la espiritualidad humana, se consigue el siguiente objetivo: la obra de arte se vuelve multisemántica, tiende a las aperturas en diferentes estratos culturales, entabla la relación dialogada con todo el universo creativo de la humanidad. Sobre el concepto de la sinsemiya en el arte, cfr. Petrov, M., La simultaneidad en el arte. Los sentidos culturales y paradojas, Indrik, Moscú, 2010, pp. 91-131. 64 Rank, O., Don Juan et le Double, París, Payot, 1990, p. 101.
} 
venir en relaciones efectivas que tienen toda la apariencia de relaciones objetuales, mientras que, de hecho, están regidas por elecciones narcisistas" 65.

El desajuste, al principio una leve fisura entre el hombre y su reflejo, genera un malestar que puede ir desde la desagradable experiencia descrita por Delacroix hasta la escisión vivida por Kerjentzev. El hombre y su reflejo dejan de ser solidarios: su divergencia toma cuerpo ante el espejo, hasta tal punto que la imagen especular se emancipa y, en último extremo, ya no es percibida como un fenómeno óptico, sino como un rival amenazador. V. Wolf y una paciente de Freud, Anna O., han dado testimonio de la experiencia traumática del encuentro con el doble, de ver a una bestia o a un monstruo en sus espejos, proyecciones tal vez de una enfermedad mental. 66

Cabe señalar que en este yo escindido, el otro, celoso o rival, constituía una condición de un doble simétrico y brillante, asegurando la posibilidad de un vaivén reflexivo, de una síntesis armoniosa o dolorosa de pulsaciones contradictorias. En su análisis sobre la trasgresión de sí mismo en el otro, Mattiussi expresa esta idea de la siguiente manera:

Esta compulsión de inventar mediante la proyección de la fantasía del otro es, sin embargo, ambigua como lo demuestra el inicio de Mrs Dalloway. Mientras la heroína pasea por Londres de forma anónima, parece dividida entre dos sentimientos contradictorios. Por un lado, la visita el deseo de anular todo el ser que el curso de su existencia le ha hecho adoptar... Por otro lado, la posible pérdida de su identidad aparece como una mutilación, de acuerdo con la causa de las exigencias de la vida social.67

La relación con el espejo seduce porque extrae su destello de este reverso del paraíso platónico que es el mundo inmóvil de la simetría y las correspondencias. Según la observación de Quignard, la imagen especular resulta más atrayente porque está desprovista de cualquier tipo de alteraciones y transformaciones: "los simulacros en las obras siempre son más fascinantes que los modelos en los que se inspiran porque las obras son menos sospechosas de la vida y de la metamorfosis. Están próximas al anquilosamiento de la belleza: les ha alcanzado la muerte"68. La percepción de la simetría misteriosa impulsa a creer que existe detrás una contrapartida invisible y mejorada de nuestra realidad cotidiana. Con respecto a eso, argumenta J. Baudrillard en Cultura y simulacro que cuanto más perfecto es el sistema de imitación, más se desvanece el sentido profundo del referente original: "no se

65 Cfr. Selma de la Hoz 2001, op. cit.(nota 52), pp.73-74.

66 Cfr. Ronnberg, A., Martin, K. (eds.), El libro de los símbolos: reflexiones sobre las imágenes arquetípicas, Madrid, Taschen, 2011, p. 592.

67 Mattiussi 2002, op. cit. (nota 37), p. 143.

68 Quignard, P., El sexo y el espanto, Barcelona, Editorial Minúscula, 2005, p. 196. 
trata ya de imitación, ni reiteración, sino de una suplantación de lo real por los signos, de lo real por su doble operativo" 69 . Además, afirma en otra obra que "la seducción es aquello que no tiene representación posible, porque la distancia entre lo real y su doble, la distorsión entre el mismo y el otro está abolida"70. La ilusión de atravesar el espejo responde a esta necesidad de participar de una doble dimensión, encontrarse a sí mismo al otro lado del reflejo. Semejante travesía constituye una trasgresión de las normas del mundo real que es posible solamente en el mundo del sueño y en el acto de la creación artística. La pintura y la poesía se presentan como equivalentes simbólicos del espejo, en tanto que, igual que éste, provocan la mirada del fascinus, ${ }^{71}$ es decir, atrapan la atención del espectador que ya no puede apartarse del objeto que contempla. De ahí que adquiera los poderes sobrenaturales, gracias a los cuales el que está involucrado en el acto de mirar, traspasa al reino de la imaginación y de la ensoñación.

En este sentido resulta ilustrativa la novela La encantadora de Florencia, de S.Rushdie 72 , en la que Dashwanth, el artista de la corte, se enamora de la imagen de la princesa que el mismo había creado, es decir, se convierte en cautivo de su propia proyección 73 . Oscilar entre la visión ensoñadora y la realidad material, carente de la dimensión espiritual, conduce al protagonista a abandonar la existencia terrenal mediante la penetración en el espacio ficticio del cuadro.

La interpretación del espejo-simulacro como modelo ontológico y recurso formal se halla también en la obra de Borges. Las imágenes especulares no solamente aparecen recurrentemente en sus escritos, sino que se establecen como principio organizativo de la estructura narrativa. Ya en 1964, Paul Moan observaba:

Esta multitud de reflejos constituye para Borges una indicación del éxito poético. Le fascinan los efectos de espejo en la literatura, tales como el drama dentro de otro drama de la época isabelina, el personaje Don Quijote leyendo el Quijote, Sheherezade que una noche empieza a recitar palabra por palabra el cuento de Las mil y una noches. Porque cada imagen reflejada en el espejo es estéticamente superior a la anterior, como el paño

\footnotetext{
69 Baudrillard, J., Cultura y simulacro, , Barcelona, Kairós, 1984, p. 11.

70 Baudrillard, J., De la seducción, , Madrid, Cátedra, 1994, p. 67.

$71 \mathrm{El}$ término es adoptado por P. Quignard en su libro El sexo y el espanto.

72 Rushdie, S., The enchantress of Florence, New York, Random House, 2008, pp. 115-126.

73 Este fenómeno se llama en el psicoanálisis el arquetipo de Narciso, cuyo concepto se ha originado en la mitología clásica y se ha utilizado para explorar los problemas de la instancia yoica. En la visión de Freud constituye un fenómeno regresivo, neurotizante y asocial de la personalidad. Por otro lado, el fenómeno del narcisismo, visto desde una perspectiva diacrónica, está considerado como el factor que induce la actividad humana en su dimensión estética; en la dimensión de la creatividad individual, el narcisismo parece ser una exigencia -en ocasiones impuesta por el aislamiento-, una entrega al objeto como elaboración proyectiva o un dispositivo de auto-observación analítica, como el que constituye el mismo proceso de la creatividad en general, que puede llegar a ser incluso un estímulo. Sobre este tema véanse, Selma de la Hoz, 2001, op, cit. (nota 52).
} 
teñido es más bello que el simple, la tradición deformada más rica que el original, el Quijote de Menard, estéticamente más complejo que el de Cervantes. ${ }^{74}$

Como un espejo cuya reflexión invierte/revierte el objeto representado, la estructura funciona como un metacomentario que califica, modificando o reforzando, los significados que el texto propone desde los signos del lenguaje: «La espera» es la historia de un asesinato, pero el relato está organizado como un péndulo que oscila entre la realidad y el sueño hasta obligar al sueño a contaminar e invadir la realidad, como a veces el espejo, en un contexto borgiano, obliga al lector a sentirse simulacro del otro que nos mira desde el fondo del cristal; estructura de espejo a través del cual la escritura obliga a los signos del lenguaje a invertirse/revertirse, generando un sentido ausente en el primer sistema. Gracias a este procedimiento los límites entre el referente originario y su imagen tienden a la abolición.

Entre los numerosos espejos que forman parte del universo metafórico de Borges, una atención especial merece la concepción de la imagen cristalina como el punto de encuentro recíproco de los simulacros, de la psyche y de su correlativo productivo, el arte, que acontece en múltiples niveles que conciernen tanto a la vida intelectual y espiritual, como a la cotidiana y trivial. El espejo aquí se identifica con la creatividad75: "a veces en las tardes una cara / nos mira desde el fondo de un espejo; / el arte debe ser como ese espejo / que nos revela nuestra propia cara"76.

En la pintura, La mujer en el espejo de Paul Delvaux es ejemplo clásico del arte como imagen del doble idealizado en el que una muchacha desnuda aparece sentada frente a un espejo. Sin embrago, la joven del cuadro no mira al espejo, mientras que la imagen de su propio rostro que muestra el reflejo, rodeado por una banda de encaje, sí que la mira a ella. La coincidencia de dos miradas divergentes en el locus ficticio del espejo testimonia la existencia real de dos sujetos totalmente independientes y equivalentes. Para Delvaux, la superficie cristalina, por tanto, constituye un cronotopo en el que se desarrolla el diálogo lúdico entre las apariencias reales e ilusorias. Asimismo, el espejo se convierte en metáfora de la imaginación abierta al infinito que se construye a partir de la noción de la polisemántica implicada en los reflejos, en el hiperbolismo de los espacios y las dimensiones.

En El doble autorretrato de Richard Estes nos encontramos ante la reflexión sobre la autorreferencialidad del artista en tanto que creador. La figura diminutiva del pintor con cámara fotográfica aparece dos veces reflejada en la fachada crista-

\footnotetext{
${ }^{74}$ Cit. por J. Alazraki, Versiones, inversiones, reversiones: el espejo como modelo estructural del relato en los cuentos de Borges, Madrid, Gredos, 1977, p. 13.

${ }^{75}$ Este motivo aparece también en el epílogo al «Hacedor», en el que Borges explica que el espejo final es el destino del escritor que «poco antes de morir traza la imagen de su cara de hombre en este paciente laberinto de las líneas».

76 Borges, J. L., «Arte poética», en Borges, J. L., Obra poética, Barcelona, Destino, 2009, p.150.
} 
lina del restaurante y en el espejo del interior. Este procedimiento es reminiscente de los modelos barrocos de los que Las Meninas de Velázquez es un buen ejemplo. El hecho de que el artista se autorrepresentara no con pincel sino con la cámara fotográfica presupone la reflexión sobre la naturaleza de estas dos artes visuales y su complementariedad. La intersección de estos dos procedimientos constituye un paso más en el camino de la ilusión. A este efecto contribuyen también la disolución del espacio interior en el exterior, el detallismo y la multiplicidad del punto de vista, todos ellos propios de la perspectiva fotográfica.

Se podría decir que la pintura de Estes es la de un autor de vedute, no exactamente en el sentido barroco del término, sino matizado éste por la cultura visual del siglo XX, en la que el fragmento, la simultaneidad y la ambigüedad son elementos característicos. La captación del instante vital, de lo transitorio, denota la verdad del momento, revela al sujeto atrapado al hilo del tiempo.

Oteiza plasma la imagen del doble en su conexión con la noción de la eternidad. Así, en La Mujer ante el espejo configura una imagen femenina como una constante atemporal, ausente de los indicios de la vida real, en un estado de petrificación etérea. La superficie refractaria devuelve una representación de un doble extraño. La imagen que aparece en el espejo está desprovista de los rasgos individuales, lo cual, a nivel plástico, se percibe en la generalización de las formas y en la tendencia a la abstracción. Los ojos de la mujer están concentrados en su reflejo, el suyo es un encuentro fascinado con el objeto de la contemplación. La mirada directa, según la interpretación de Quignard, está relacionada con la toma de conciencia. Este proceso de la individualización remite al estado de la desintegración, al momento de la disolución de los tiempos: la muerte coincide con el nacimiento. A este respecto, en un poema dice el escultor vasco:

Mi imagen en el espejo no coincide conmigo, le ocurre algo raro/ parece independiente de mí, /sonrío y yo no sonrío en el espejo dejo pasar unos momentos/me echo a un lado yo sigo en el espejo/ pero soy mi imagen en algún día anterior/ mi tiempo en el reloj/ ahora mi tiempo en el espejo atrasaba / observo, sigo a un lado unos momentos sin imagen/ aparece otra persona en el espejo que no conozco/ en mis manos tomo el espejo/ lo sacudo con violencia/ quiero ver si esa imagen cambia o se va / y aparece el rostro de un anciano muy anciano/ soy yo mismo, tardo en reconocerme ahora el tiempo en el espejo adelantaba. 77

Desde la época del Renacimiento, la invención del arte pictórico, en general, y del género del autorretrato, en particular, se relacionan con la superficie transparente. De ahí que para comprender las características del motivo del espejo en su relación con el doble en el arte contemporáneo sea importante detenerse brevemente en el análisis de algunos ejemplos pictóricos.

77 Oteiza, J., «El tiempo en el espejo», Archivo Jorge Oteiza, registro 7659. 
F. Bacon en su Figura escribiendo en un espejo pinta un autorretrato en el que aparece la figura masculina, prácticamente desnuda, arrinconada, sentada enfrente de una pared que realmente traspasa para escribir sobre una mesa, al tiempo que un espejo en la pared nos devuelve su imagen en una posición contraria a la que lógicamente debería mostrarnos. Por otro lado, un elemento representativo, cuya forma podría recordar el respaldo de un taburete, une a la figura real con su imagen especular. Según indica Navarro de Zuvillaga, este anhelo de transformación de la realidad previamente deformada, este deseo de multiplicación de los espacios y figuras y de creación de contrapartidas visuales divergentes, está ligado al concepto de simultaneidad propio del arte contemporáneo: la expresión de una sensación dinámica a través de la descomposición del movimiento, la yuxtaposición de múltiples puntos de vista, el contraste de los colores puros y en definitiva, la interacción conflictiva del tiempo, movimiento y espacio ${ }^{78}$.

Son únicos en cuanto a su concepción espacial, los autorretratos de M. C. Escher. El artista se representa a sí mismo en el reflejo de una bola especular, como ocurre en Mano con la esfera especular, 1935 y en Tres esferas II, de 1946; así como se representa en un espejo redondo en Autorretrato, 1943. En el arte de Escher abundan los elementos relacionados con el reflejo, los laberintos visuales, la simetría y la asimetría. La concepción estética del pintor está determinada por el trabajo del intelecto frío, el juego mental, la precisión matemática y la imaginación sin fin son componentes que fijan la mirada del espectador en laberintos y ornamentos especulares construidos en la perspectiva "incorrecta".

El principio del desdoblamiento nos es revelado de una manera distinta en la obra de Pollock. En el cuadro Retrato y Sueño, el pintor estadounidense modela los paradigmas visuales del antagonismo entre la mímesis y el gesto expresivo de los colores y de las líneas. En el tratamiento de la figura humana, el creador del abstraccionismo utiliza el principio de la duplicación. La composición se organiza en torno al motivo de la cabeza que posee cualidades figurativas y abstractas simultáneamente. El rostro masculino, que guarda parentesco con el prototipo humano, se difumina poco a poco hasta desenvolverse en una imagen abierta constituida por líneas y manchas. Esta parte no figurativa alude a la identidad del artista, pues la pintura para él es el sueño y el objetivo único.

\section{El espejo andrógino}

El tema del desdoblamiento implicaría contemplar el desarrollo del mito de la androginia en la cultura contemporánea. Su relación con el reflejo se origina en la versión del mito presentada por Pausanias, según el cual, Narciso tenía una herma-

78 Navarro de Zuvillaga 2000, op. cit. (nota 7), p. 112. 
na gemela a la que amaba por ser su doble original. Tras su muerte se vuelca sobre su reflejo en la búsqueda del amor perdido de su infancia79. Bachelard expresa así la naturaleza mixta de este símbolo arquetípico: "ante las aguas, Narciso tiene la revelación de la identidad y de su dualidad, la revelación de sus dobles poderes viriles y femeninos, sobre toda la revelación de la realidad y de su idealidad"80. En última instancia, es la síntesis reconciliadora de todas las oposiciones, de la coincidentia oppositorum que resuelve y anula todas las tensiones nacidas de la división y de la existencia correlativa de parejas de opuestos. Desde el punto de vista del psicoanálisis, el fenómeno de la androginia está relacionado con el arquetipo de anima/animus. Cabe señalar que es un concepto de "carácter androcéntrico" 81 que se manifiesta en la imagen de las sicigias trascendentales, en la unión entre lo masculino y lo femenino. Así lo expresa K. G. Jung: "en el inconsciente se encuentra un contenido de elevada tensión emocional que en cierto momento llega a ser proyectado. El contenido es el tema de la syzygia, que expresa que en lo masculino siempre se da al mismo tiempo lo correspondiente femenino" 82 .

La simbología hermafrodita está implícita también en la formulación de las categorías estéticas de mímesis y arte. Según la observación de Libis, los arquetipos ascienden a la superficie y alimentan la producción de los artistas. El encuentro amoroso surge en el fondo del ensueño solitario del individuo separado, impregna el movimiento de la imaginación/creación individual cuando ahonda en sí misma y descubre los esquemas fundamentales que estructuran y dinamizan. La belleza también está relacionada reversiblemente con el andrógino, su evocación parece convertirse en una especie de ideal bipartito que se manifiesta en una cierta uniformización de los rasgos femeninos y masculinos. La fusión andrógina vivifica la antigua relación del doble / reflejo / / eros / muerte, puesto que es allí donde acontece la simbiosis entre las parejas primordiales, que se manifiesta en su compenetración y enfrentamiento mutuos. Este proceso tiene lugar en el círculo metabólico del eterno retorno: "lo que los dos amantes desean inconscientemente es fundirse entre sí, matar su individualidad para tener, posteriormente, una muerte común. En sentido estricto, el andrógino no puede ser reconstruido más que cuando cada mitad abandona definitivamente sus límites particulares" 83 . En el discurso mitológico, el mundo se origina en una androginia primordial, y esta ambivalencia concierne tam-

\footnotetext{
79 Cfr. Frontisi-Ducroux, Vernant 1997, op. cit. (nota 6), pp. 217-221.

80 Bacherlard 1994, op. cit. (nota 32), p. 42.

81 Es un término utilizado por Demaris Wehr que remite a los modelos psicológicos generados por los hombres y las mujeres los unos con respecto a las otras, determinados por las proyecciones propias de cada sexo. Cfr. Wehr, D., «Animus: el hombre interior», en Dowling, Ch.(dir.), Espejos del yo: imágenes arquetípicas que dan forma a nuestras vidas, Barcelona, Kairós, 1994, p. 62.

82 Jung, C. G., Arquetipos e inconsciente colectivo, Barcelona, Paidós, 1970, p. 61.

83 Libis, J., El mito del andrógino, Madrid, Siruela, 2001, p. 242.
} 
bién a los dioses y a los antepasados. El mito del andrógino encarna la depresión ontológica causada por la pérdida de la unidad armoniosa inherente a la existencia primogénita. De ahí la tesis de Ferenczi: "el coito es el intento de volver a este estado ideal del paraíso perdido. El contacto sexual permite un retorno a la situación intrauterina. El coito no puede tener por objeto más que un intento del yo de volver al cuerpo materno" 84 . Por otro lado, el tema de la bipartición contiene implícitamente el del incesto y de la gemelaridad. Como afirma Rank: "la idea de que los gemelos se han creado a sí mismos me parece manifestarse de manera evidente en la extendida creencia de que los gemelos de sexo diferente pueden realizar el acto sexual ya antes de su nacimiento, y transgredir así el tabú de exogamia"85. En literatura el modelo bipartito puede hallarse con frecuencia en varios autores, entre los que destacaremos a V. Woolf, R. Musil y H. Hesse.

Con Musil asistimos al drama del anhelo existencial de la simbiosis con su mitad gemela de sexo femenino. El personaje Ulrich de la novela El hombre sin atributos se dirige a su hermana Ágata: "imagina dos peces rojos en un bocal [...]. No nos preocupamos por saber si son dos o uno solo en realidad [...]. Lo que me pregunto es cuándo podrán tener ese sentimiento [...]. Para ellos, a cada instante del ser doble que forman, corresponden dos posiciones del mundo que, psíquicamente, pueden coincidir, es decir, jamás tendrían la impresión de una distancia entre los dos, ni nada semejante" 86 .

En El lobo Estepario de Hesse, la imagen de Hermina en su manifestación hermafrodita es el reflejo tanto de Harry, como del propio escritor: el nombre Hermina se presenta, explícitamente, como el equivalente femenino de Herman, el nombre de Hesse. El juego de alusiones onomásticas designa también a Hermina como un punto de anclaje que permite al autor estar presente en su ficción, tanto en ella como en el personaje principal, Harry Haller, que lleva las mismas iniciales que Herman Hesse 87 . La imagen de la mujer joven tiene rasgos hermafroditas; por un lado, Hermina está dotada del poder de seducción inherente a la belleza femenina y para Harry representa el símbolo fusionado de la hermana ${ }^{88}$, la madre y la amada ${ }^{89}$, por otro, es caracterizada también como un adolescente hermoso 90 .

Asimismo, la joven es "el espejo mágico" de la bipartición ficticia del personaje/autor. Sin embargo, ella no constituye una simple duplicación de los mismos, sino que configura lo que Bachelard llamaba "un modo activo del narcisismo", ya

\footnotetext{
${ }^{84}$ Ferenczi, S., Thalassa, psychoanalyse des origines de la vie sexuelle, Paris, Payot, p.44.

85 Rank 1990, op. cit. (nota 64), p. 81.

86 Musil, R., El hombre sin atributos, cit. por Libis 2001, op. cit. (nota 83), p. 199.

87 Cfr. Mattiussi 2002, op. cit. (nota 37), pp.159-160.

88 Cfr.Hesse 1959, op. cit. (nota 37), p. 159.

89 Cfr. Ibidem, p. 101

90 Cfr. Ibidem, pp. 115-116.
} 
que no se limita a devolver la imagen sino que pretende transformar lo que refleja. Este proceso se desarrolla mediante el sistema de órdenes que le da a su doble masculino: "recibirás muchas órdenes mías y las acatarás [...]"91. Tras cumplirlas, éste logra liberarse de su individualidad gastada, impregnada del espíritu de la seriedad y de la pesadez y se vuelve capaz de penetrar en el mundo lúdico de la música, del baile, de la risa y del eros en su estado puro: "hoy, en esta bendita noche, irradiaba yo mismo esta sonrisa, nadaba yo mismo en esta felicidad honda, infantil, de fábula; respiraba yo mismo este dulce sueño y esta embriaguez de comunidad, de música y de ritmo, de vino y de placer sexual [...]"92.

El arquetipo andrógino de la mímesis está implícito en las reflexiones de Woolf que estima que la creación en sí y sus potenciadores, los artistas, en el sentido más amplio, están impregnados del espíritu andrógino: "[...] en cada uno de nosotros dominan dos fuerzas, una masculina, otra femenina [...].El estado normal y satisfactorio es aquél en el que dos sexos viven en armonía y cooperan en el orden espiritual. Es cuando tiene lugar esta fusión cuando la inteligencia es fertilizada por completo y puede hacer uso de todas sus facultades"93.

La aplicación del espejo como metáfora del Tánatos y Eros es identificada en la literatura surrealista. Así, la imaginería cristalina y refractaria se utiliza en los textos surrealistas para hablar de la androginia concebida como la transformación del principio femenino en el masculino dentro del acto coital. Asimismo, a la mujer se le concede un papel activo en este proceso transgresor. La superficie transparente se convierte en metáfora del cronotopo mágico en el que acontece la contracción y la metamorfosis mística de los principios opuestos. Como lo propone G. Legrand: "nos sentiríamos tentados de decir que en la androginia de complementarios se perfila un andrógino de los suplementarios, en el sentido geométrico del término. La mujer representaría aquí, desde el punto de vista del hombre, el papel de la «gota del ser» vertida en una solución ya saturada y transformada en el cristal"94.

Por otro lado, el tema del amor en su relación con el concepto de androginia se percibe en la poética surrealista como la experiencia de la muerte y del horror, pues la unión primordial requiere el sacrificio de la abnegación en favor del ser amado. Así, en el poema de L. Aragón La muralla de roble leemos: "no imagino el amor sin que se mezcle en él el sabor de la muerte"95.

Resulta interesante observar que una meditación sobre la mímesis coincide aquí con la idea mítica de la plenitud bisexual, que se auto-reproduce y expresa así la

\footnotetext{
91 Ibidem, p. 117.

92 Ibidem, pp. 176-177.

93 Woolf, V. cit. por Nathan, M., V. Woolf par elle-même, Paris, Seuil, 1956, pp. 88-89

94 Legrand, G., «El dilema de la androginia», cit. por Benayoun, R., Érotique du surréalisme, Paris, Pauvert, 1965, p. 127.

95 Aragon, L., «La muralla de roble», cit. en Ibidem, p. 131.
} 
naturaleza pletórica de su constitución. En las artes figurativas, se aprecia la misma insistencia en la representación de las syzygias. En este sentido, una mención especial merece la figura de Chagall, ya que elabora las variaciones sumamente sofisticadas de este modelo ontológico. En su obra podemos distinguir las imágenes que pertenecen a la categoría de $d u$-partzufin (el cuerpo con doble rostro) y las que ilustran la androginia (el hermafroditismo) ${ }^{96}$. Su origen se explica en las fuentes del jasidismo, en la noción de la bipartición divina, que constituye el modelo de la dualidad de $\operatorname{sexos}^{97}$. En la extensa obra de Chagall encontramos abundantes representaciones de este tipo. Así, relacionadas con el primer modelo puede apreciarse, entre otras, el plato de cerámica Cara verde doble, en el que la trama central se organiza a partir del rostro bipartido que reúne los rasgos femeninos y masculinos.

El motivo del andrógino aparece por vez primera en la obra de Chagall en 1911 con la obra Homenaje a Apollinaire. El foco central de la composición está constituido por una esfera gigante con los números que se conciben como metáforas del $\operatorname{cosmos}^{98}$. En este espacio circular se inscribe la figura masculina entrecruzada con la media figura femenina, de manera que las dos se fusionan en un ser único. La manzana en la mano de este cuerpo andrógino alude al pecado original y permite identificar la imagen como la unidad mística de la pareja primogénita. Según el mito del Génesis, el hombre fue creado de las cenizas y después Yahvé creó a la mujer de la costilla de Adán (Génesis 2:22). Sin embargo, Chagall no sigue el Antiguo Testamento, sino que opta por una versión cabalística que sin duda conocía, teniendo en cuenta su formación intelectual y el ambiente cultural jasídico en el que se había criado. Según esta tradición, el hombre al principio estaba constituido por el andrógino enorme con doble cara. Estas representaciones andróginas sirvieron al artista bielorruso como punto de partida en el desarrollo de esta temática en su obra ulterior 99 .

La imaginería que evoca una androginización letal es hallada en las creaciones plásticas de Brancusi. Así, en su obra titulada El beso, el escultor rumano confunde a los amantes en una amalgama de piedra que anula las diferencias de los sexos al mismo tiempo que borra los signos externos de la vida: el andrógino surge aquí en la petrificación de un vago paralelepípedo mineral en el que la fluidez de los fenómenos biológicos no tiene espacio.

La revelación andrógina en su sentido de la creación o mímesis nos es revelada en el cuadro $\mathrm{Al}$ revés en el que Jean Hélion representó al artista sentado ante dos

\footnotetext{
96 Cfr. Idel, M., Kabbalah and eros, London, Yale University Press, 2005, pp. 58-59.

97 Cfr. Libis 2001, op. cit. (nota 83), pp. 43-48.

98 Cfr. Meyer, F., Marc Chagall. Life and work, New York, H. N. Abrams, 1964, p. 161.

99 Véanse, por ejemplo, sus ilustraciones para la Biblia publicadas en la revista Verve X no. 37/38, más concretamente Creación, 1960, 26,3, 35,9 cm., litografía en color. Cfr. Sorlier, Ch., Mourlot, F., Chagall-Litograph, 1957-1962,vol. II, Monte Carlo, Andrés Sauret, 1963. cat. no. 241.
} 
figuras semánticamente contrarias. A su derecha, en un escaparate vidriado, está expuesta su obra abstracta El equilibrio. A la izquierda, en una proximidad inmediata al autorretrato, ante una ventana abierta, aparece la imagen de una mujer desnuda invertida. La oposición entre la metáfora del acto creativo humano, encarnado en la imagen del lienzo experimental in vitro, y el acto creativo divino manifestado en la modelo in vivo se intensifican mediante la antinomia andrógina. Así, en la parte izquierda predomina la figura del desnudo femenino, mientras que el lado derecho, de por sí relacionado con el principio masculino, está reservado a la figura del pintor y a su similitud, el cuadro, la metáfora de la acción que anuncia el potencial productivo del artista. Según nos indica Bachelard, "una imagen que sugiere un acto debe evolucionar en el inconsciente del femenino al masculino" 100 . Por otro lado, el carácter andrógino es subrayado en tanto que el doble del cuadro contiene implícitamente el germen de la figura humana, probablemente masculina. El diálogo entre los dos principios conceptualmente opuestos se establece gracias al juego ilusorio de las superficies cristalinas.

\section{Conclusión}

El espejo crea el doble de lo visible y, como cualquier creación humana, entabla una relación dialogada con el tiempo. El espejo con el que el mundo puede establecer un diálogo lúdico, en el que puede balancearse o presentarse en inesperado o grotesco escorzo atrae a los artistas y pensadores de la época moderna. La imagen reflejada en la superficie cristalina carece de los indicios representativos concretos, se deconstruye o remite a una realidad desconocida. Esta percepción de la ausencia visual no significa necesariamente la abolición del yo en el mundo contemporáneo, sino el mayor grado de profundización en la comprensión del ser y de sus condicionantes. La imagen vacía, fragmentada o transformada remite a la multiplicidad del ser, a su complejidad existencial, lo cual coincide con nuevos logros en el ámbito de las ciencias y del psicoanálisis. Por otro lado, la contemplación de la nada en la superficie refractaria hace posible la penetración en el espacio trascendental. La recurrencia de este motivo en el arte plástico y literario y en el pensamiento contemporáneos, en su relación con lo supra-terrenal, refleja la preocupación por la dimensión metafísica. El espacio vacío o fragmentado se concibe también como una sustancia diáfana que facilita la entrada en el muro transparente del sueño, de la poesía y del arte. Otra vertiente de este motivo está constituida por la pluralidad conceptual del espejo. Es una pantalla transparente entre lo real y lo imaginario, el mundo heterotópico y su contrapartida invertida. Del mismo modo, implica la opo-

100 Bachelard 1994, op. cit. (nota 32), p. 62. 
sición entre las posibilidades limitadas del ser y su inmanencia; antinomia entre el conocimiento de la verdad y la impotencia humana ante su despliegue infinito.

La noción del doble en su relación con el motivo del espejo presenta rasgos polisémicos en su evolución. Podemos identificar varios niveles interpretativos: 1 . la percepción del doble como monstruo, rival amenazador; 2. el doble como la antinomia amor propio/muerte; 3 . el doble como símbolo de la creación artística y de la imaginación; 4. el doble como módulo ontológico donde el espectador/lector se convierte en simulacro del mundo imaginario; 5. el doble como metáfora cronotópica; 6. el doble como paradigma entre la mímesis y el gesto expresivo abstracto.

Como los chimpancés jóvenes que se muestran excitados y confusos la primera vez que se ven a sí mismos en un espejo, ${ }^{101}$ así el hombre contemporáneo contempla estupefacto su inconsciente en las construcciones mitológicas que tienen su raíz en el concepto de la androginia. Según la sutil observación de Groddeck, "todos los símbolos son más o menos bisexuales"102, de ahí que para entender la psique humana poblada de imágenes primordiales, a saber, arquetípicas, sea necesario acceder a la interpretación del modelo bipartido. En este sentido, la noción de androginia se vincula con el problema de la reflexividad. La densidad de su contenido se determina a través de siete elementos: desdoblamiento / gemelaridad / incesto / reflejo / mímesis / juego / muerte / eros. Por último, la superficie transparente del cristal se convierte en el campo de atracción simultánea entre distintas ciencias y artes. Los elementos figurativos se entrelazan y crean un ritmo común, inherente a la naturaleza de las cosas y al baile mental que se exterioriza en la conciencia humana. Los sintagmas visuales y conceptuales establecen un diálogo lúdico que rompe las fronteras de las limitaciones humanas y accede a las dimensiones desconocidas hasta entonces o exploradas de una manera implícita103. El espejo se convierte en metáfora de la transformación conceptual del mundo y de la personalidad humana. Un papel fundamental en esta reestructuración de la imagen del espejo es la que desempeña el psicoanálisis en tanto que permitió reconsiderar los problemas del autoconocimiento y profundizar en la comprensión del universo y del ser. Es también digno de mención el que las teorías psicoanalíticas se encuentran en una relación inmediata con el desarrollo de las nuevas tecnologías y la creación de nuevos espacios sociales.

La cultura moderna y posmoderna configuran múltiples interpretaciones semánticas de la imagen del espejo. Las creaciones plásticas y literarias, así como las especulaciones filosóficas del siglo XX sorprenden por la variedad y el volumen de

\footnotetext{
101 Cfr. Gardner 1990, op. cit. (nota 29 ), p. 1.

102 Goddeck, G., Le livre du ça, Paris, Gallimard, 1973, p. 191.

$103 \mathrm{La}$ visión griega contiene de forma interiorizada algunos de los elementos relacionados con la noción del espejo que serán claves para la cultura contemporánea, como la idea del espejo vacío y el doble, entre otros.
} 
las obras que desarrollan la temática del espejo. El estudio del concepto del espejo en el devenir histórico revela una profunda relación entre la semántica del objeto y los procesos estéticos, axiológicos, gnoseológicos y religiosos.

El sujeto del siglo XX al mirarse al espejo se interroga sobre su identidad e inventa su propia condición de visibilidad. El espejo abre un diálogo intercultural y traza las pautas de la metamorfosis continua de la vida y de la condición humana. 